УДК 330.5 .051
JEL I3, R1
DOI https://doi.org/10.17721/tppe.2019.38.2

Sokołowska-Woźniak D, Ph.D., Assistant Professor, Wyższa Szkoła Biznesu - National Louis University

Woźniak D., Ph.D., Assistant Professor, Wyższa Szkoła Biznesu - National Louis University

\title{
INCOME DISPERSION IN POLAND. AN ANALYSIS IN YEARS 2005 - 2018 BASED ON INDIVIDUAL INCOMES OF POLISH GMINA'S (COMMUNES) IN NUTS 2 AND NUTS 3 UNITS
}

Presented paper addresses the issue of income inequalities among regions in Poland. Although the topic is broadly discussed both in scientific literature and public debates, the problem of territorial cohesion still remains important for many scholars and politicians. In the article the main attention is focused on the measuring the wealth and its dispersion which is coherent with the current public data state and enables following the phenomena in all statistical units of NUTS nomenclature and local administrative units (local self-government entities: poviats and gminas). In the calculations presented in the paper gminas' own resources are taken into consideration as a measure of welfare, then Theil index is employed to identify the dispersion for aggregated date on NUTS 1,2,3 units for post-accession to European Union structures period. Authors used the data delivered by the Central Statistical Office.

Keywords: regional disparities, NUTS classification, Poland, Theil index, convergence

Formulation of the problem. Income disparities among regions are the object of interest of many scholars and policy makers. The importance of the phenomena is reflected in the sustainable development goals declared by the United Nations in 2016 [1]. The European Commission plays a notable role in this area as body responsible to maintain the goal of convergence in EU policy (cohesion policy) and a initiator of multiple economic study on this phenomena, with the Reports on economic, social and territorial cohesion in particular[ 2]. Poland, after joining European Union in 2004, considered the goal of territorial cohesion as one of the most important goal of state policy. At present, indicators of Strategy for Responsible Development are set on maintaining the current inequality level in 2030 in the area of economic cohesion [3]. These indicators include: differentiation of gross value added per person employed in total at the regional level (NTS 2) in total; differentiation of gross value added per person employed by section $A$ at the regional level (NTS 2); differentiation of GDP per capita at sub-regional level (NTS 3). 
Monitoring the situation in regions, discussing used measures of wealth, measures of dispersion and factors influencing the phenomena is still the object of research. In this particular case, data availability remain a driver for looking for further study.

Analysis of recent publications. Economic, social and territorial cohesion is a subject of investigation of many scholars and practitioners (i.e. politicians). The term of economic convergence refers to the situation in which poorer economies will tend to grow at faster rates than richer economies. In consequence, such economies will become more coherent, in of the welfare distribution. In theory a distinction between two types of convergence can be found:

- $\beta$-convergence when the partial correlation between growth in income over time and its initial level is negative and

- $\sigma$-convergence when the dispersion of real per capita income (henceforth, simply "income") across a group of economies falls over time.

Breakthrough papers in "convergence literature" were written by Barro and Salai- Martin [4] and Mankiw et al. [5]. Their findings suggest that convergence process can be found in all analyzed examples (US states, EU regions, Japan prefectures). And the speed of the $\beta$-convergence process is around 2-3 percent per year, see also [6].

Despite the literature's stress on $\beta$-convergence, economists have acknowledged that it is not a sufficient condition for $\sigma$-convergence. Quah [7] and Friedman [8] both suggest that $\sigma$-convergence is of greater interest since it speaks directly as to whether the distribution of income across economies is becoming more equitable. In this paper the authors follow that suggestion made by Quah and Friedman. 
In the mentioned above Seventh report on economic, social and territorial cohesion, main findings were connected with recovery of EU economy after recession and the convergence process across European Union countries and regions [2]. The crisis halted the long-term reduction in disparities in GDP per head between Member States. With the beginning of the recovery, however, these disparities have started to shrink again. Narrowing disparities at regional level across the EU also should be mentioned. Between 2000 and 2015, GDP per head in many less developed regions converged towards the EU average through faster productivity growth, but they lost employment. The regions with GDP per head well above the EU average grew faster than the less developed ones through a combination of both productivity and employment growth. As most of the higher GDP per head regions contain a national capital or a large city, they benefit from agglomeration economies for a bigger labour market contributes to a better matching of skills.

According to the study of Matkowski, Prochniak and Rapacki [9], during the last 26 years, the Polish economy has experienced a fast real convergence vis-à-vis both EU countries and all transition economies. The improvement in Poland's relative development level was primarily due to its economic growth - the fastest among the new EU members from Central and Eastern Europe, and more than twice as fast as the average for the "old core" (EU15). Poland and these two groups of countries had similar economic growth trajectories from 2004 to 2015, after Poland's EU entry. The same was true of the 2010-2015 period.

Studies focused on internal situation in Poland, however, identify divergence. Czarnecki, Szarota and Woźniak research on voivodeships situation in 1998-2008 confirms the divergence process in income per capita level and economic efficiency, measured with DEA method [10]. An analysis of Wójcik in NUTS 2 and 3 regions in years 1995-2005 lead to the same conclusions. The only type of convergence was the existence of convergence clubs among group of regions with similar income level, it means regions considered "poor" tend to converge towards one another and create a convergence club at a low level of per-capita wealth [11]. The same process (increasing inequalities) was identified in the study carried for years 1995-- 2020 (2007-2020 based on Hermin model forecasts) by Kudłacz and Woźniak [12]. Additionally, the authors noticed, that the measures of EU would not be effective to diminish the differences. However, they could decrease the polarization. 
Similar trends were found by Tvrdon and Skokan in their analysis of 2000-2006 GDP per capita differences among regions in Visegrad group countries [13]. A noticeable increase in regional disparities was related mainly to the differences between metropolitan areas and the rest of regions in the countries.

According to the study of Wójcik [14] carried out for years 2000-2014, Poland's accession to the European Union did not have a positive impact on the process of convergence of regional income, and has accelerated the divergence process. In accordance with his conclusions, in the period after Poland's accession to the EU neither beta nor sigma convergence was observed. The fastest growing regions were Warszawa, other large cities and the regions abounding in natural resources. In general, subregions in the surveyed period were more often becoming poorer than richer.

Interesting study was conducted by Pietrzak and Balcerzak [15] at the level of subregions (NUTS3) for the years 2004-2012, in which Poland's territory was divided into two areas. The division into a highly developed western area and the significantly less developed eastern area was adopted. The authors concluded polarization of economic development at the regional level based on the adopted division into sub-regions.

Poland's EU accession allowed the strong development of the sub-regions of the western area that was then already characterized by a good socio-economic situation; on the other hand, however, the process of the European integration did not cause the same positive effect for the eastern area, where a much weaker socio-economic situation improved but to a small degree only.

All of above mentioned studies were using national/regional accounting measures of income level (standard of living). An alternative to GDP measure of a local development, called the aggregated index of an economic development, was used in the econometric analysis performed by Kisiała for years 2004-2014 [16]. The results indicate a decrease in the level of inequalities across poviats in Poland; but the $\beta$-convergence pace was very slow.

Unsolved parts of the problem. There is a lack of the elaborations using nonstandard (non-regional accounts related) measures of wealth, which are available on the local level.

The purpose of the article. The purpose of the article is twofold. The methodical goal is to find an alternative for national/regional accounts measures like GDP, GNI or GVA per head, which could be used to monitor local/regional wealth and the wealth distribution in different territorial dimensions, starting from gmina (the basic unit of administrative division in Poland, selfgovernmental) to macroregion (level 1 NUTS unit). Additionally, the trends in income inequalities in Polish regions corresponding to the NUTS 1, 2, and 3 after the accession to the EU structures (1st of May 2004) to the 2018 will be identified. 
Research methodology. Due to the fact, that regional accounts measures (GDP, GVA) are not available at local level Authors suggest gmina's own resources (revenues) per head as a measure of wealth. Generally, the sources of gminas' revenues are as follows: own revenues, general subsidy and targeted subsidies from the state (central) budget. The structure of the all self-governmental entities revenues is presented in table 1.

Table 1.

Percentage of selected categories of local self-government revenues in 2013.

\begin{tabular}{|l|l|l|l|l|l|}
\hline $\begin{array}{l}\text { Structural } \\
\text { indicators }\end{array}$ & Total & Gminas & $\begin{array}{l}\text { Cities with } \\
\text { poviat } \\
\text { status }\end{array}$ & Poviats & Voivodeships \\
\hline Total revenue & $100 \%$ & $100 \%$ & $100 \%$ & $100 \%$ & $100 \%$ \\
\hline $\begin{array}{l}\text { Own resources in } \\
\text { the strict sense }\end{array}$ & $28,9 \%$ & $31,2 \%$ & $36,8 \%$ & $14 \%$ & $7,5 \%$ \\
\hline $\begin{array}{l}\text { Transfers from } \\
\text { state budget }\end{array}$ & $62,1 \%$ & $63,3 \%$ & $55,1 \%$ & $77,9 \%$ & $60 \%$ \\
\hline Other revenues & $9 \%$ & $5,5 \%$ & $8,1 \%$ & $8,1 \%$ & 32,5 \\
\hline
\end{tabular}

Source: [17].

It is worth noting, that the system of own revenue for local self-government entities in Poland is characterized by a low fiscal importance of most local taxes and a high contribution of revenues from shares in PIT and CIT in financing local self-government. Very strong correlation (Pearson coefficient $=0,99$ ) between the own resources and GDP can be observed [18].

The data were acquired from Local Data Bank of the Central Statistical Office in Poland [19]. Statistical territorial division NUTS was used for aggregating the data. Classification of Territorial Units for Statistics (NUTS) is a geographical standard used for a statistical division of the EU Member States economic territories into three regional levels of specified classes of the population. It has been established in order to enable the collection, compilation and dissemination of harmonized regional statistics in the European Union.

As of January 1, 2018, 97 NUTS units operate in Poland:

- $\quad$ NUTS 1 - macro-regions (grouping voivodships) - 7 units

- $\quad$ NUTS 2 - regions (voivodships or parts thereof) - 17 units

- $\quad$ NUTS 3 - subregions (grouping poviats) - 73 units.

The division of the territory of Poland on NUTS units are shown on figures 1-3. 


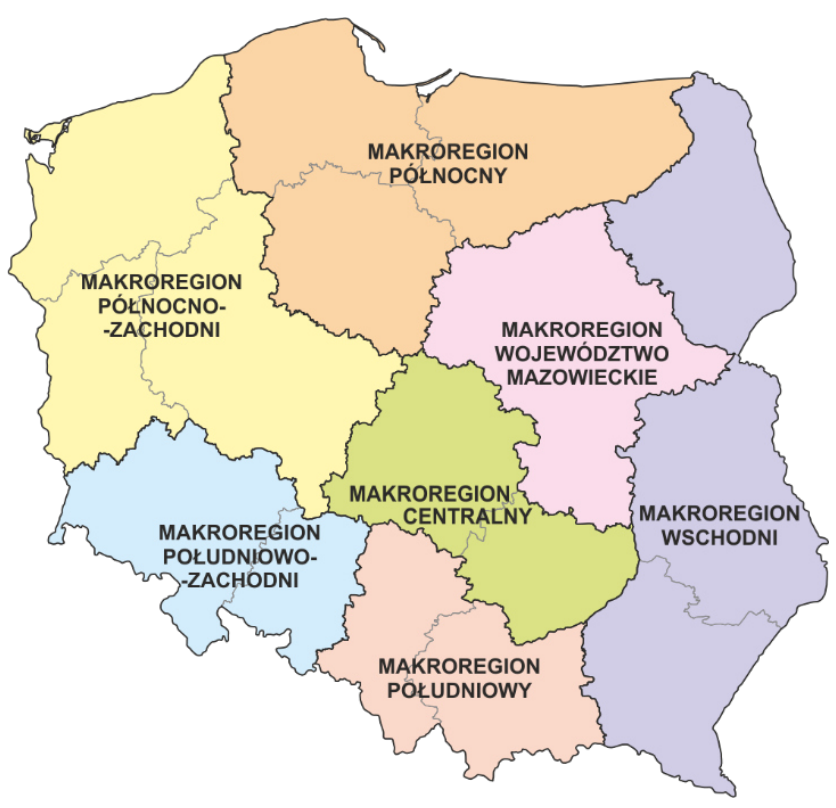

Figure 1. The division of the territory of Poland into the macroregions (NUTS 1 units) Source: [20]

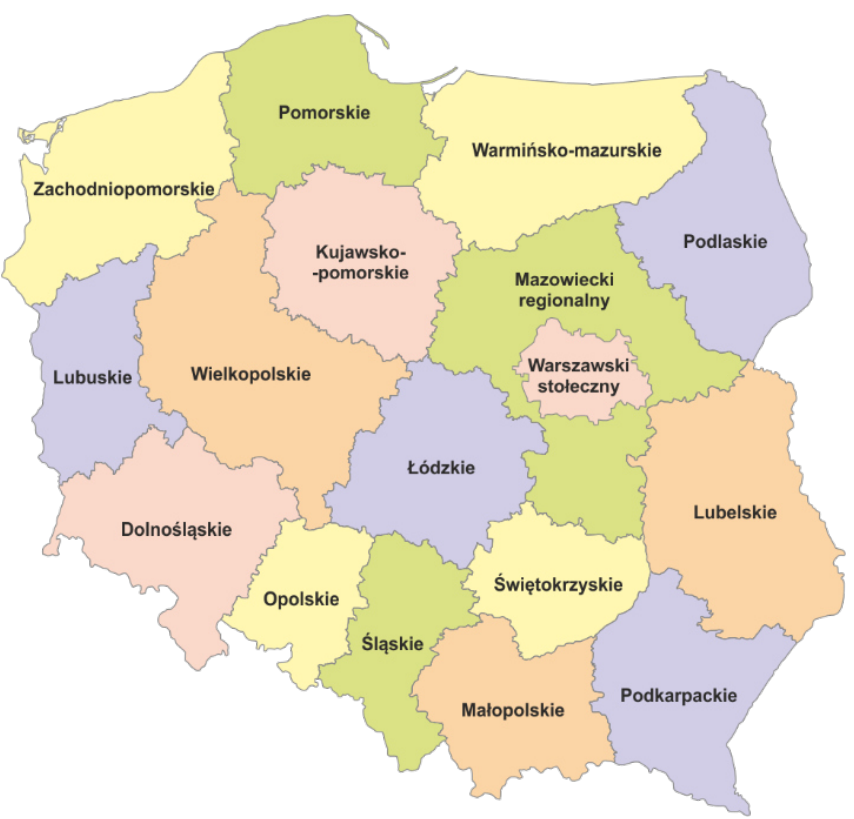

Figure 2. The division of the territory of Poland into the regions (NUTS 2 units) Source: [20] 


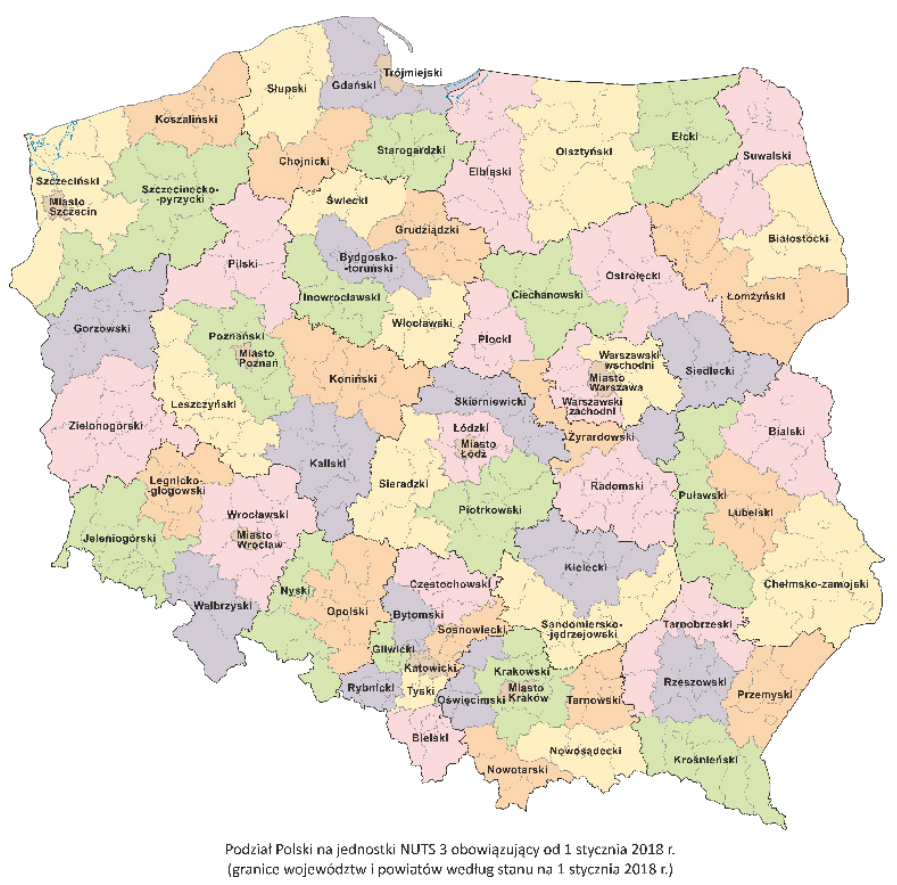

Figure 3. The division of the territory of Poland into the subregions (NUTS 1 units) Source: [20]

For measuring the inequalities among regions, Theil index was used [21]. The general formula of the index is given:

$$
\mathrm{I}_{\mathrm{T}}=\sum_{\mathrm{i}=1}^{\mathrm{n}} \frac{\mathrm{Y}_{\mathrm{i}}}{\mathrm{Y}} \ln \frac{\frac{\mathrm{Y}_{\mathrm{i}}}{\mathrm{P}_{\mathrm{i}}}}{\frac{\mathrm{Y}}{\mathrm{P}}}
$$

where $\frac{\mathrm{Y}_{\mathrm{i}}}{\mathrm{Y}}$ represents the share of each region in the total product (here product stays for gminas' own revenues aggregated for Poland) of the regions and $\frac{\mathrm{Y}_{\mathrm{i}} / \mathrm{P}_{\mathrm{i}}}{\mathrm{Y} / \mathrm{P}}$ represents the relation of the product per capita of each region to the product per inhabitant of regions taken as a whole (Poland). The Theil index can vary between 0 and $\ln \frac{\mathrm{P}}{\mathrm{P}_{\mathrm{i}}}$. Maximum value of $\ln \frac{\mathrm{P}}{\mathrm{P}_{\mathrm{i}}}$ means that the whole of the product is concentrated in the region where the population is smallest and value equal zero means perfect equality in regional product per head. The important (however not used in the current research) characteristic of Theil index is the possibility of aggregation into sub-assemblies, which enables splitting the variation into sub categories.

Research results. The data on the level of own revenues per capita are presented in figures 4-6. In case of NUTS 1 units (Figure 4), Makroregion Województwo Mazowieckie (with capital city of Warszawa) showed the greatest results (almost 4 thousand of PLN), which is over two times better than Makroregion Wchodni (east part of Poland). The differences between the rest of macroregions are relatively small.

Taking into account the NUTS 2 level (Figure 5), we can observe the dominant position of region including Warszawa, with the level of income $76 \%$ higher than the second (region Dolnoślaskie). The poorest regions are Świętokrzyskie, Podkarpackie and 
Lubelskie (below 2 thousand of PLN). It is worth emphasizing the relatively huge differences in Mazowieckie voivodeship (administrative unit), between the Region Warszawski Stołeczny and Region Mazowiecki Regionalny.

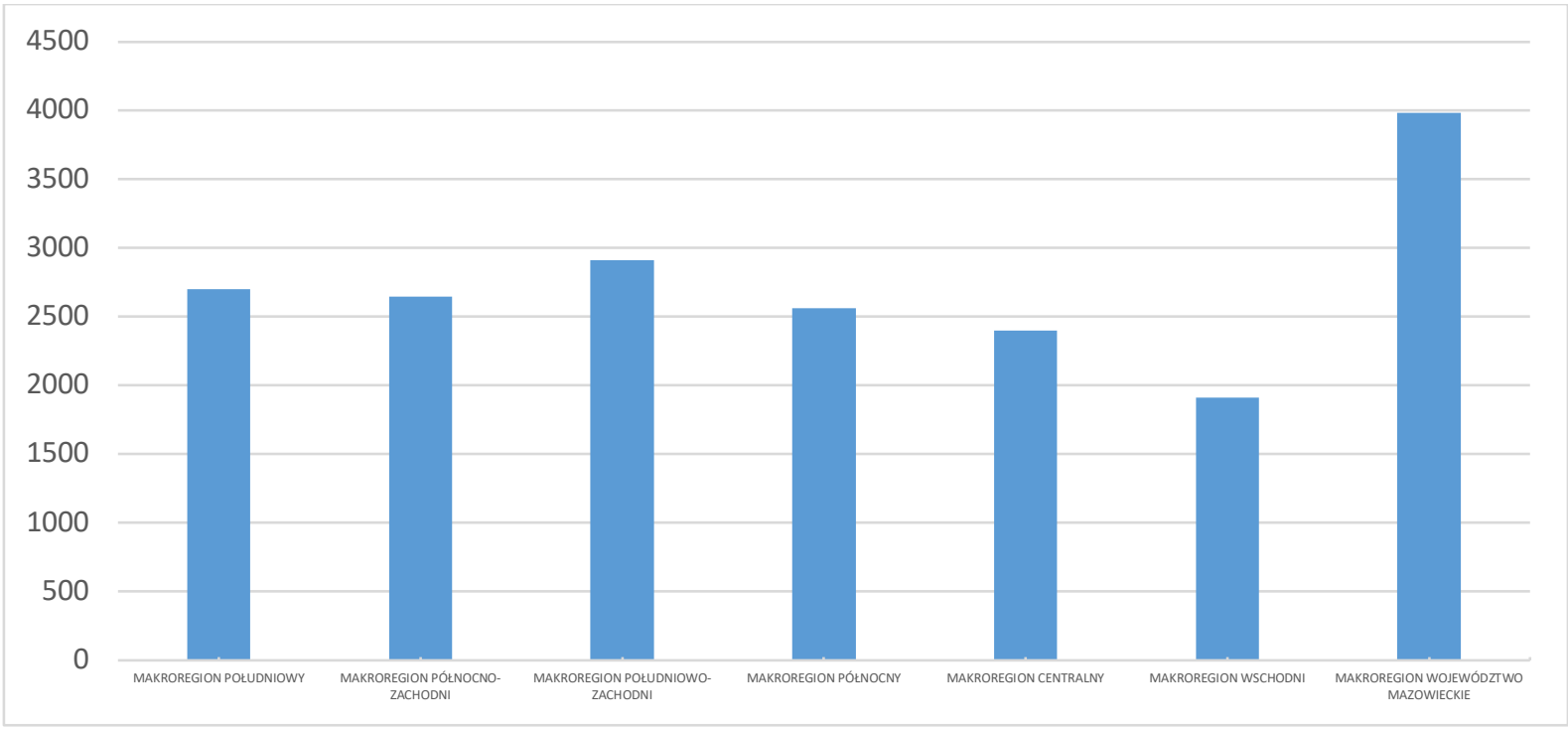

Figure 4. Own revenues per inhabitant in NUTS 1 units in Poland in 2018

Source: own calculations based on (Local Data Bank 2019)

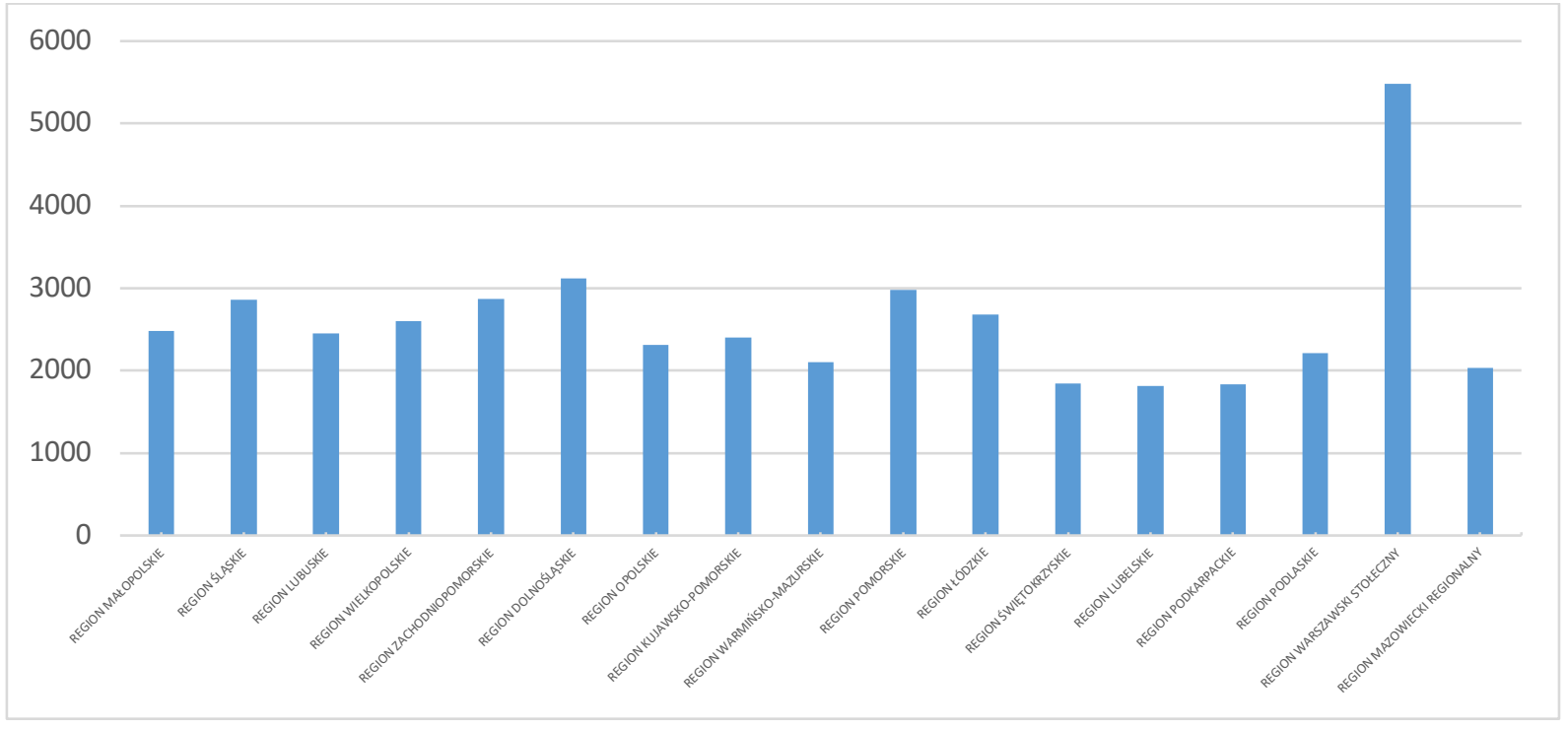

Figure 5. Own revenues per inhabitant in NUTS 2 units in Poland in 2018

Source: own calculations based on (Local Data Bank 2019) 
The differences between big cities and other subregions could be clearly seen analyzing subregions. Warszawa, Wrocław, Kraków, Poznań and Gdańsk (Trójmiasto) have the value from the range of 4 to 5 thousands of PLN, while the average (arithmetic mean) for Poland is 2,7 thousands of PLN.

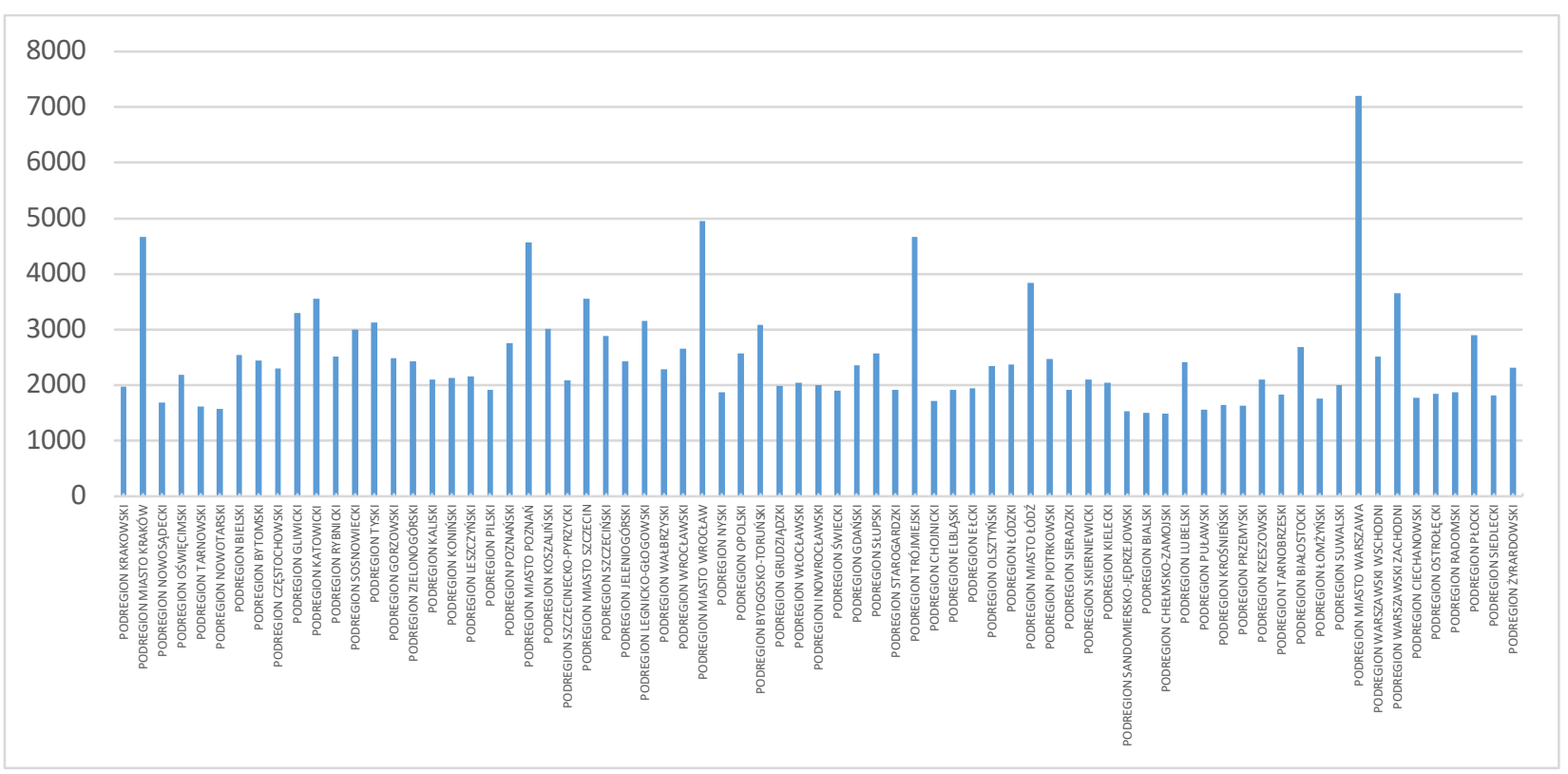

Figure 6. Own revenues per inhabitant in NUTS 3 units in Poland in 2018 Source: own calculations based on (Local Data Bank 2019)

Theil index calculations for all NUTS unit levels are presented in Figure 7. Taking into account the extreme values of the index (2,29-2,34 for macroregions, 3,63-3,66 for regions and 5,31-5,33 for subregions) it should be stressed, that the general level of inequalities in Poland is relatively low. Contrary to main findings from the literature, the decreasing values of the Theil index suggest convergence process in all levels (starting from 2006). The higher the level of NUTS units, the differences becomes lower.

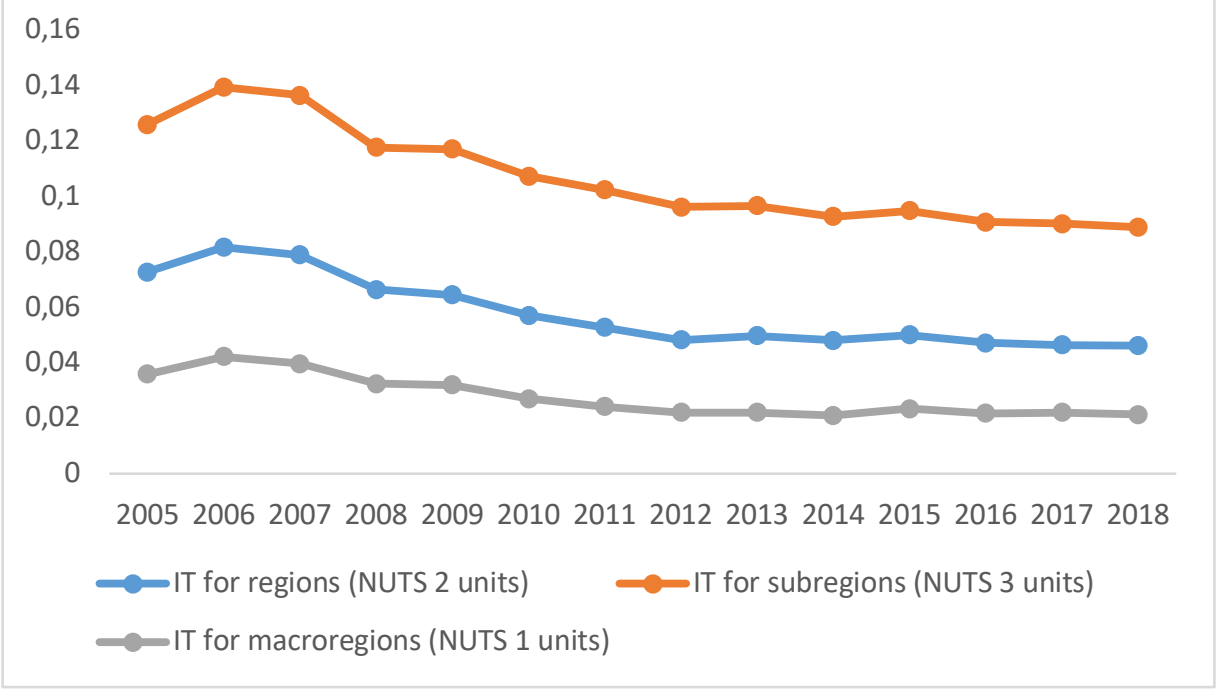

Figure 7. Theil index values based on gminas' own revenues in years 2005-2018 Source: own calculations based on (Local Data Bank 2019) 
Conclusions. Referring to the goals of the article, conducting of the research enabled to draw two following conclusions.

Measures of wealth used in the convergence analysis are derived from national/regional accounts statistics. They are mainly depended on the place of creating value (like GDP). On the local/regional level it is recommended to analyze the situation of residents. So, other measures like gminas' (basic local administration unit) own resources, based on personal and commercial income tax should be at least parallelly taken into consideration.

An analysis of the convergence process inside the country, carried out for Polish NUTS 1, 2 and 3 administrative units in years 2005-2018, based on gminas' own resources as a standard of living measure, showed different (opposite) patterns than the results of studies using national/regional accounts measures. Starting from the year 2006 the convergence process (sigma type) is observed in all levels of statistical regions in Poland.

Prospects for further research. The results of analysis, presented in the paper suggest deeper research of the phenomena of inequalities among regions and local units. Further directions should be defined as follows:

- an analysis of the inequalities on the poviat level, possible linking the results with the specific feature of Theil index, namely the possibility of aggregation into subassemblies.

- a comparative study of the convergence process based on the national/regional account measures and own revenues of local administrative units, leading to the findings which are more appropriate measures of well-being.

\section{Bibliography}

1. United Nations. "Transforming our world: The 2030 agenda for sustainable development." ,2016.

2. European Commission. "My Region, My Europe, Our Future: Seventh Report on Economic, Social and Territorial Cohesion". Publications Office of the European Union, 2017.

3. Ministerstwo Rozwoju. Departament Strategii Rozwoju. "Strategia na rzecz odpowiedzialnego rozwoju: do roku 2020 (z perspektywą do 2030 r.)", 2017.

4. Barro, Robert J., and Xavier Sala-i-Martin. "Convergence." Journal of Political Economy 100, no. 2 (1992): 223-251.

5. Mankiw, N.G., D.H. Romer, and D.N. Weil. "A Contribution to the Empirics of Economic Growth." Quarterly Journal of Economics, 1992: 407-437.

6. Young, A.T., M.J. Higgins, and D. Levy. "Sigma Convergence Versus Beta Convergence: Evidence from U.S. County-Level Data." Journal of Money, Credit and Banking, 2008: 1083-1093.

7. Quah, D. T. "Galton's Fallacy and the Convergence Hypothesis." Scandinavian Journal of Economics, 1993: 427-443.

8. Friedman M., "Do Old Fallacies Ever Die?" Journal of Economics Literature, 1992, 30: 21292132.

9. Matkowski, Zbigniew, Mariusz Prochniak, and Ryszard Rapacki. "Income Convergence in Poland vis-à-vis the EU: Major Trends and Prospects." In Poland. Competitiveness Report 2016. The Role of Economic Policy and Institutions, by Marzena Anna Weresa, 37-55. Warsaw: SGH Warsaw School of Economics, 2016. 
10. Czarnecki, Piotr, Robert Szarota, and Dariusz Woźniak. "The Analysis of Convergence Process of Voivodships' Efficiency in Poland Using the DEA Metod." New Challenges for European Regions and Urban Areas in a Globalised World. Barcelona: European Regional Science Association, 2011.

11. Wójcik, Piotr. "Dywergencja czy konwergencja: dynamika rozwoju polskich regionów." Studia regionalne i lokalne, 2008: 41-60.

12. Kudłacz, Tadeusz, and Dariusz Woźniak. "Konwergencja czy polaryzacja rozwoju regionalnego Polski w perspektywie 2020 r. w świetle projekcji modelu HERMIN." Zarządzanie Publiczne, 2009: 19-32.

13. Tvrdon, Michal, and Karel Skokan. "Regional disparities and the ways of their measurement: the case of the Visegrad four countries." Technological and Economic Development of Economy, 2011: 501518.

14. Wójcik, Piotr. "Was Poland the next Spain? Parallel analysis of regional convergence patterns after accession to the European Union." Equilibrium. Quarterly Journal of Economics and Economic Policy, 2017: 593-611.

15. Pietrzak, Michał Bernard, and Adam P. Balcerzak. "A regional scale analysis of economic convergence in Poland in the years 2004-2012." In Regional Studies on Economic Growth, Financial Economics and Management, 257-268. Cham: Springer, 2017.

16. Kisiała, Wojciech. "Zmiany nierówności poziomu rozwoju gospodarczego powiatów w Polscekonwergencja czy dywergencja?" Prace Naukowe Uniwersytetu Ekonomicznego we Wrocławiu, 2016: 127-135.

17. Guziejewska, Beata. "Designing a revenue structure in local self-government entities in Poland: Taxes versus grants." Quarterly Journal of Economics and Economic Policy, 2015: 45-63.

18. Chmiel, Justyna, and Rafał Pitera. The importance of fluctuations in the economic situation for own revenues of Local Government Units. Vol. 56, in Nierówności społeczne a wzrost gospodarczy, 246258. 2018.

19. Local Data Bank. 10 31, 2019. https://bdl.stat.gov.pl/BDL/start.

20. Central Statistical Office. 10 31, 2019. https://stat.gov.pl/statystyka-regionalna/jednostkiterytorialne/klasyfikacja-nuts/klasyfikacja-nuts-w-polsce/.

21. Theil, Henri. Statistical Decomposition Analysis with Applications in the Social and Administrative Sciences. Amsterdam: North Holland Publishing, 1972.

Соколовская-Вужняк D., к.э.Н., доцент,

Высшая школа бизнеса - Национальный университет Луиса

Вужняк Д., к.э.Н., доцент, ректор

Высшей школы бизнеса - Национального университета Луиса

\section{ДИСПЕРСИЯ ДОХОДОВ В ПОЛЬШЕ НА ОСНОВЕ АНАЛИЗА ДОХОДОВ ПОЛЬСКИХ ГМИН (ТЕРРИТОРИАЛЬНАЯ ЕДИНИЦА) 3А 2005 - 2018 ГОДЫ}

В статье освещены проблемы неравенства доходов в различных регионах Польши. Основное внимание сконцентрировано на измерении богатства и его дисперсии. В процессе анализа использовались доходы польских гмин, которые учитывались как мера благосостояния, индекс Тейла был использован для идентификации дисперсии. Исследования проводились в период после присоединения Польши к Европейскому Союзу и были использованы данные предоставленые Центральным статистическим управлением Польши.

Ключевые слова: региональные различия, классификация NUTS, Польша, индекс Тейла, конвергенция 
Соколовська-Вужняк D., к.е.н., доцент,

Вища школа бізнесу - Національний університет Луїса

Вужняк Д., к.е.н., доцент, ректор

Вищої школи бізнесу - Національного університету Луїса

\section{ДИСПЕРСІЯ ДОХОДІВ В ПОЛЬЩІ НА ОСНОВІ АНАЛІЗУ ДОХОДІВ ПОЛЬСЬКИХ ГМІН (ТЕРИТОРІАЛЬНИХ ОДИНИЦЬ) \\ ЗА 2005 - 2018 РОКИ}

В статті висвітлено проблеми нерівності доходів в різних регіонах Польщі. Основну увагу приділено виміру багатства та його дисперсії. В процесі аналізу використовувались доходи польських гмін, які враховувались як міра добробуту, індекс Тейла був використаний для ідентифрікації дисперсії.

Дослідження проводились за період після приєднання Польщі до Європейського Союзу та були використані дані надані Центральним статистичним управлінням Польщі.

Ключові слова: регіональні відмінності, класифрікація NUTS, Польща, індекс Тейла, конвергенція 